\title{
The Househelp in African Literature and Its Implication for Identity Representations: Evidence from Adichie's Select Prose Fictions
}

\author{
Angela Ngozi Dick \\ Correspondence: Angela Ngozi Dick, Veritas University, Abuja, Nigeria. \\ Received: June 28, 2019 \\ Accepted: September 10, 2019 \\ Online Published: September 12, 2019 \\ doi:10.5430/elr.v8n3p35 \\ URL: https://doi.org/10.5430/elr.v8n3p35
}

\begin{abstract}
Househelps are usually boys and girls who go to live with other families to serve as domestic workers. They are usually not paid but their services are converted training them in school or in entrepreneurial empowerment. Their place in African Literature has been explored in Oyono's Houseboy to portray colonialist policy of assimilation. In Ekwensi's Jagua Nana's Daughter, the househelp takes over the home as the protagonist combines the search for her mother and her carrier as a lawyer. Adichie's prose fictions are inundated with househelps. This article probes the roles of househelps in the development of the plot and finds out that they are portrayed as human beings with rights and privileges. Such portrayal is determined by the attitude of their Masters or Madams. In Purple Hibiscus, the househelp shares in the subjugation of the family because of the harsh treatment of their father. In Half of a Yellow Sun and "Imitation", the househelps participate in the decision making around food and emotional problems of their Masters and Madams. The author's portrayal of the househelps brings into focus the need to accept this category of people as human beings to be valued. The literary theory that will inform the analysis of the texts is New Historicism propounded by Stephen Jay Greenbalt.
\end{abstract}

Keywords: househelp, sisterhood, New Historicism

\section{Introduction}

New Historicism is a literary theory espoused by Greenbalt in 1989. The insight from Bertens below demonstrates some fundamental concerns of Greenbalt's New Historicism. Influenced by Foucault, this theory interrogates the relationship between the beliefs of a critic, his social status, and the literary, historical understanding of literature. It also investigates the power relations between the powerful and the disempowered, using the prevailing political ideas of the period in the literary text (Bertens 2008: pp.142- 146). Thus, New Historicism is a literary theory that engages the past and the present in the critical analysis of a literary text.

On the other hand the house-help is a boy or a girl ill-fated to be orphaned, born by poor parents, forcefully ejected or graciously transferred from his family to live with another family for economic reasons. Such children do not choose who to live with or the geographical location. They do domestic work ranging from cooking, washing babysitting, tending the garden or any other work specified by the head of the child's new family. In extreme cases the child may be confused in terms of whom to obey when there is proliferation of headship or instruction in this new family. At the extreme, the child loses the orientation of his family of origin and as Frantz Fanon would put it in The Wretched of the Earth (1963, 2008 Edition )" cultural obliteration is made possible by the occupying power, by the banishment of the natives and their customs to outlying districts . . (p.190). Sometimes, the child is hunted by food and shelter insecurity, prone to physical, verbal and sexual abuse by the members of his adopting family. The circumstances of the child's family may be a determinant of how he or she is treated.

In literary works, the house-help is crafted according to the conflict and thematic preoccupation of the author. In Achebe's Things Fall Apart (1958), Ikemefuna is a war exchange for Udo's wife murdered by a neighbouring village called Mbaino. Although Okonkwo rules his household with a heavy hand (p.9), Ikemefuna begins to feel like a member of his new family (p.25) calling Okonkwo father. Ikemefuna is symbolic of conflict resolution strategies in traditional Igbo land before the incursion of western influences. Ikemefuna gives historic insight into the structure of power in Igboland that time, but there is no exchange of prisoners in the configuration of power, diplomatic and conflict resolutions in Igboland now.

In Achebe's collection of short stories entitled Girls at War and Other Stories (1972), the househelp in the "Vengeful Creditor" takes revenge on her mistress , Mrs Emenike by poisoning baby Goddy with red ink so that she can enroll 
in free primary education(66). The treatment of the househelp by the Emenike family comes close to the vestige of patriarchy in which some societies still disallow girl child education. Vero is supposed to be invisible. But in Idu, published by Nwapa in 1970, Nwapa narrates househelp desertion in which Uzoechi's daughter is abandoned to scream for her absent mother who was then laundering in the village stream $(I d u, \mathrm{p} .1)$. The narratives in both Achebe and Nwapa show contrasting actions taken by househelps in vehement disapproval of forced domestic work and the search for freedom.

Although, Ferdinand Oyono's Houseboy (1975 edition) is a political discourse of colonial French policy on assimilation of its colonies, the houseboy, Joseph Toundis is devoted to Reverend Father Gilbert, his master. Although the master wields more power, his treatment of the househelp is benevolent. While his bones revolt to the long period of serving mass (serves up to three or four masses p.17), Joseph is grateful to Father Gilbert and other missionaries and proudly tells the reader:

I am his boy, a boy who can read and write, serve mass, lay a table, sweep out his room and make his bed. I don't earn any money. Now and again he gives me an old short or old pair of trousers (pp.14-15).

Gakwandi (1977), submits that the "young houseboy is made to record his experience with pride instead of bitterness" p.(14).

The discussion above leads to the main thrust of this article, which is the position of the househelp in Adichie's select prose fictions. The prose fictions include the short story entitled "Immitation" published in the collection The Thing around Your Neck (2009), the novels Purple Hibiscus (2005) and Half of a Yellow Sun (2007).

\section{The Househelp in Friendship and Companionship in The Thing Around Your Neck}

In Adichie's "Immitation", the househelp, Amaechi travels with her mistress, Nkem, to live in Philadephia in the United States of America (The Thing Around Your Neck, p.25). Her husband, Obiora, leaves her in the United States of America to do business in Lagos, but lives in concubinage with a Benin girl in Lagos, Nigeria (p.33). Wealthy men in Nigeria own houses overseas, re-locate their families there, visit their families when it is convenient but live in concubinage with other women ready to accept such relationships in Nigeria. One of the tenets of New Historicism is to "flatten and homogenize" all literary subjects (Bertens,p146). In this short story there is no incidence or episode of maltreatment rather Nkem acknowledges her maid's superiority in certain aspects of domesticity like peeling yam (p.32). Through this form of sisterhood their love for Nigerian food is resonated. Nkem also confides in her maid about her husband's infidelity with the Benin girl. Ijemamaka's phone gossip is heart breaking and reductionist. Bonding with Amaechi strenghtens Nkem to affirm her personal opinion about her married life, although she is still plagued by full time housewife and poverty in her natal family. Nkem recaptures her individuality in friendship with her maid, sharing drinks with her to celebrate her citizenship in America and to repress the rising anger in her heart after the phone gossip with Ijemamaka.

Besides, bonding with Amaechi engages her to retain the Nigerian kinship and culinary model as different from American food and family individualism. Nkem lacks the strength of character, deferring always to her husband's decisions but the narrative with Amaechi sets a new direction for her. They will return to Nigeria because marriage cannot be crammed into irregular visits "(The Thing Around Your Neck p.41)". In the words of Emecheta (2007), Nkem has grown not to "continue to endure either mental or physical brutality of her husband" (p. 555). Therefore, she is strengthened to dialogue with her husband.

When Obiora visits again, she studies his body and realizes he does not carry a perfect physiology, thus intimating awareness of the true nature of the man she married. Prior to the ritual drink, her body hygiene is determined by Obiora's taste to match his status as a big man. She becomes more self confident to conduct her body hygiene for her wellbeing and not to match her husband's status. Obiora observes the change and remarks thus : "I liked your long hair better. You should grow it back. Long hair is more graceful on a big man's wife "(The Thing Around Your Neck, p.40)". Amaechi is relevant both as a domestic servant and as a catalyst for Nkem's psychological well being. Adichie's approach to the role of the househelp is true and depicts reality. Power relations are blurred to the advantage of human rights and freedom.

\section{The Good Master Househelp in Half of a Yellow Sun}

Ugwu, a naturally intelligent boy from Opi, is plotted as a dynamic personality affecting other characters and controlling the settings in Half of a Yellow Sun. He is not crafted as being on transit but as one who has come to live with his master, Odenigbo, in perpetuity. Casting the slough of village timidity, he learns how to speak good English, cook, wash, iron, buy from the market and run other domestic errands satisfactorily. Odenigbo calls him: "my good 
man" (p11). However, he fears that the arrival of Olanna might disrupt the balance of his life with his master (pp.25-48). Rather Olanna accepts him, assists him in laundry, gives him presents to enhance his body hygiene (p.48). The characters are also flattened as in the short story. Odenigbo treats him as his equal: "Call me Odenigbo", he mentions to Ugwu (pp. 13\&17). This leads Ugwu to realize he is better than Dr. Okeke's houseboy:

Ugwu came to realize other things. He was not a Normal houseboy. Dr Okeke's houseboy next door did not sleep on a bed in a room, he slept on the kitchen floor. The houseboy at the end of the street with whom Ugwu went to the market did not decide what would be cooked, he cooked whatever he was ordered to. And they did not have masters or madams that gave them books saying,' This is excellent, just excellent' (p.17).

Through Ugwu, the reader feels the shrewdness of other Masters and Madams in relation to their househelps. Olanna's mother calls Maxwell "wild animal" (p.220) for stealing what Olanna quantifies as not more than four cups of rice (p.221). While Maxwell's action qualifies as theft, it is not on the scale of theft by politicians, Olanna reasons. Ugwu is thirteen when he comes to live with Odenigbo, but as the novel ends he has grown and educated enough to complete Richard's research as he leaves for his own country because of the uncertainty trailing the end of NigeriaBiafra war. The task to complete Richard's book entitled "The World Was Silent When We died" completes Ugwu's growth as a male adult. Dedicating the book to Odenigbo, his master, is an appreciation of the opportunity his master has given him to grow up under hope, possibilities and options to realize his dreams (p.433). Ugwu's transformation brings hope to a people bewildered by corrupt politicians, insensitive rulers, insecurity, food scarcity and defective policies on education. Ugwu's faculty developed in linguistic competence, reading and writing. This childhood experience places him on the podium of completing Richard's story. His intellectual growth finds expression in what Onukaogu and Abalogu (2009) concludes about the importance of Children's Literature:

[The] child is generally informed and enlightened about the world and the society. This also ensures the future of the literary discipline, because for children on whom literature makes an early, fundamental impression, the excitement to pursue its aesthetic and artistic promises may eventually transcend the frontiers of mere childhood curiosities (p.236).

The title of Ugwu's novel will hold an eternal reality except as Uko (2008), submits:

As long as the Nigerian civil war remains a potent source of outrage, inter-ethnic hatred, discrimination, and intense nepotism, the bogey of insanity will remain among Nigerians, and the proper healing and development of the brutalized Nigerian mind and spirit, as well as the land, will remain an illusion (p.58).

Adichie's creation of househelps that are valued sufficiently as human beings, interact with their Masters and Madams on equal terms and freedom is the recognition of the rights of the househelps as human beings and portrays the author as a human rights activist.They are capable of learning and teaching their Masters and Madams within the ambience of domestic but especially culinary knowledge. Ugwu learns how to cook fried rice from Olanna while letting Odenigbo know the value of the native spice in soup. In Eisenberg's estimation, Adichie's poetic role: "obliges her to employ her special cultural status in order to voice protests against injustice" (2013, p.10). The aesthetics of African family life is strikingly portrayed in Half of a Yellow Sun and the short prose "Imitation". The aesthetics of African family life in Purple Hibiscus finds expression in Aunty Ifeoma's blissful home while family life in Eugene's family is plagued by religious fanaticism (Anusiem-Dick 2009, pp.98-109).

\section{Househelp and Sisterhood in Purple Hibiscus}

Sisterhood refers to bonding in which women are in companionship and friendship based onsimilarity in the experiences each of them had had in life. It is the similarity of experience that bonds them. Dick (2015: p.786) citing is of the opinion that through sisterhood, women can share the type of intimacy another unrelated women can provide. In sisterhood the emphasis is on companionship rather than on sexual or lesbian relations which is strange in Igboland.

Friendship between or among people is driven by care, respect and sharing knowledge about one another's life. In Purple Hibiscus, Sisi is the househelp. Her personality is split between loyalty to Eugene her Master and sisterhood with Beatrice, her Madam. Eugene treats everybody with minimal respect. For example, during lunch he is seen washing his hands in a bowl of water held by Sisi (p.19). She is not called by her name whenever her attention is needed, rather the ringer is pressed. However, the ringer that dangles from the ceiling is one of the many signifiers of Eugene's wealth. Her chores among others include washing and cooking (pp.27 29). Sisi is not left out in Eugene's strictness and obsession for order. Consequently, she manifests high, angular, cheek bones that gives her "eerily 
amused expression" (p.43). She shares in their silence and apprehension and the consequence is far reaching. As the narrative progresses, Sisi becomes Beatrice's soul sister in pain and provides the poison that kills Eugene. However, Kambili is seen in the kitchen cooking moi-moi with Sisi which is an expression of Sisi's ability to teach a younger person culinary expertise. While Madam is occupied with the plan to release Jaja from prison, Sisi takes charge of the daily activities at home. The death of the Master is a relief to Sisi whose scope of domesticity enlarges and her managerial ingenuity is displayed. The househelps extend family relations, portraying interdependency of human nature. People need one another for different reasons. However, such relationships should be benevolent and elevating especially in a changing world where human life is defiled and destroyed irrationally.

\section{Conclusion}

Greenbalt's New Historicism is a literary theory that interprets a Literature based on the social and historical experiences in the text. The househelps are human beings that have come to live with other families for many reasons. The househelps in Adichie's select prose fictions are represented as valued human beings capable of learning and teaching their Masters and Madams within the ambience of domesticity but especially through culinary ingenuity. In "Imitation", Amaechi's belief in marriage mitigates Nkem's pain about her husband's (Obiora's) unfaithfulness. This propels Nkem's resolution to return to Nigeria in order to protect her marriage from the bizarre Benin girl. In Half of a Yellow Sun, Ugwu who comes to live with his master as an illiterate village boy, learns to speak good English like his master and graduates as a creative writer. On the other hand Sisi's subterranean fear of Madam's death through wife battery prompts her to suggest a silent but definite cure for this continual, pitiless domestic violence by her Master. As Master dies, Sisi remains with the surviving members of Achike family. Her job description enlarges to include managing the home while Madam is negotiating the release of Jaja from prison, making decision about what food to prepare for Jaja. Surely Adichie has shown that househelps are valuable and should be treated as such. This is profound in a world where human life is defiled and destroyed irrationally.

\section{References}

...... (2009). The thing around your neck. Lagos: Farafina.

Achebe, C. (1958). Things fall apart. Essex: William Heinemann.

Adichie, C. N. (2006). Half of a yellow sun. Lagos: Farafina.

Anusiem-Dick. A. N. (2009). Gender, family cohesion, the African family and religious fanaticism in Adichie's purple hibiscus. Currents in African literature and the English Language.University of Calabar, pp.98-109.

Bertens, H. (2008). Literary theory: The basics. $2^{\text {nd }}$ Edition. New York: Routledge. https://doi.org/10.4324/9780203939628

Dick, A. N. (2015). Beyond the MDGs: The intersection of sisterhood in African Literature. $4^{\text {th }}$ International Conference of the Institute of Women, Gender and Development Studies, Federal University of Technology Owerri, 25-28 May 2015. Eds. Ihuoma P. Asiabaka et al. pp 784-787.

Eisenberg. E. (2013). "Real Arica' / 'Which Africa'?: The critic of mimetic realism in Chimamanda Ngozi Adichie's short fiction”. Ed. Ernest N. Emenyonu. African literature today 31 London: Heinemann, pp. 8-24.

Emecheta, B. (2007). "Feminism With a Small f". African Literature: An anthology of criticism and theory.Eds. Tejunola Olaniyan \& Ato Quason. Malden: Blackwell Publishing, pp. 550-560.

Fanon, F. (2008). The wretched of the earth. (2008 Edition). England: Penguin Books.

Gakwandi, S. A. (1977). The novel and contemporary experience in Africa. London: Heinemann Educational Books.

Onukaogu, A. A., \& Onyerionwu, E. (2009). $21^{\text {st }}$ century Nigerian literature: An introductory text. Ibadan: Kraft Books.

Oyono, F. (1975 Edition). The houseboy. London: Heinemann.

Uko, I. (2008). Of war \& madness: A symbolic transmutation of the Nigeria-Biafra war in select stories from The insider: Stories of war and peace from Nigeria. Ed. Ernest N. Emenyonu. African literature today 26. London: Heinemann, pp.49-59. 